\title{
Metal and nutrient dynamics on an aged intensive green roof
}

\author{
A.F. Speak ${ }^{\mathrm{a}, *}$, J.J. Rothwell ${ }^{\mathrm{a}}$, S.J. Lindley ${ }^{\mathrm{a}}$, C.L. Smith ${ }^{\mathrm{b}}$ \\ ${ }^{a}$ Geography, School of Environment and Development, The University of Manchester, Arthur Lewis Building, Oxford Road, Manchester M13 9PL, UK \\ ${ }^{\mathrm{b}}$ College of Science and Engineering, University of Leicester, Bennett Building, University Road, Leicester LE1 7RH, UK
}

\section{A R T I C L E I N F O}

\section{Article history:}

Received 14 May 2013

Received in revised form 20 August 2013

Accepted 23 August 2013

\section{Keywords:}

Green roofs

Lead

Urban runoff

Water pollution

\begin{abstract}
A B S T R A C T
Runoff and rainfall quality was compared between an aged intensive green roof and an adjacent conventional roof surface. Nutrient concentrations in the runoff were generally below Environmental Quality Standard (EQS) values and the green roof exhibited $\mathrm{NO}_{3}{ }^{-}$retention. $\mathrm{Cu}, \mathrm{Pb}$ and $\mathrm{Zn}$ concentrations were in excess of EQS values for the protection of surface water. Green roof runoff was also significantly higher in $\mathrm{Fe}$ and $\mathrm{Pb}$ than on the bare roof and in rainfall. Input-output fluxes revealed the green roof to be a potential source of $\mathrm{Pb}$. High concentrations of $\mathrm{Pb}$ within the green roof soil and bare roof dusts provide a potential source of $\mathrm{Pb}$ in runoff. The origin of the $\mathrm{Pb}$ is likely from historic urban atmospheric deposition. Aged green roofs may therefore act as a source of legacy metal pollution. This needs to be considered when constructing green roofs with the aim of improving pollution remediation.
\end{abstract}

(C) 2013 Elsevier Ltd. All rights reserved.

\section{Introduction}

One of the problems of growing urbanisation is the potential for high pollutant loads in urban storm runoff (Rocher et al., 2004). Urban runoff can have significant adverse ecological effects in receiving water bodies. Heavy metals in particular have been found to be highly persistent and toxic to aquatic flora and fauna at low environmental concentrations (Pizzol et al., 2011). Nutrients can also be a problem when urban surface waters discharge to water bodies that are already nutrient-rich, resulting in eutrophication (Ellis and Mitchell, 2006). The poor water quality of urban runoff results from the accumulation of particulate matter and dissolution of environmentally harmful substances as it is conveyed over the impervious roofs and roads in the urban watershed (Lye, 2009). On rooftops these substances include: heavy metals leached from roof surface materials (Rocher et al., 2004); dry and wet deposited air pollutants such as $\mathrm{SO}_{2}$ and $\mathrm{NO}_{x}$ (Fowler et al., 2007); airborne dusts from vehicle use, industry, construction (Robertson et al., 2003; Göbel et al., 2007); and salts from road de-icing (Lundmark and Olofsson, 2007). The distribution and concentration of pollutants in runoff is related to the nature of the surfaces (Mendez et al., 2011), as well as local patterns of wet and dry atmospheric deposition (Forster, 1999). This Urban Diffuse Pollution (UDP) can be difficult to identify, measure, and control, but there is nonetheless a

\footnotetext{
* Corresponding author.

E-mail addresses: andrew.speak@postgrad.manchester.ac.uk, andyspeak33@ gmail.com (A.F. Speak).
}

need to control UDP sources in order to preserve water resources from the pressures of urbanisation and climate change (DEFRA, 2011). One way to control UDP is to employ catchment based measures such as Sustainable Urban Drainage Systems (SUDS). These are preferable because they involve the multiple agencies identified in the process of UDP generation (DEFRA, 2012). They also place a greater emphasis on improving the quality of the water resource by sequestering pollutants where possible (CIRIA, 2007). SUDS technologies that improve the hydrological function of rooftops, such as green roofs, have the potential to be a great benefit for alleviating the problem of UDP, because roofs can account for $50 \%$ of the urban impervious area in the UK (Dunnett and Kingsbury, 2004).

The ability of green roofs to reduce the volume of stormwater runoff has been frequently reported (Getter et al., 2007; Stovin et al., 2012) with runoff retentions of between $50 \%$ and $100 \%$ (Rowe, 2011). Green roofs are also efficient at capturing air pollution such as $\mathrm{NO}_{x}, \mathrm{SO}_{2}$, ozone (Currie and Bass, 2008), and $\mathrm{PM}_{10}$ (Speak et al., 2012) and it is generally expected that the pollutants would be retained in the vegetated roof or consumed in reactions (Berndtsson et al., 2009). However, there is the possibility that air pollution that has been captured by vegetation will eventually leach into the roof runoff, thus trading air pollution for water pollution (Rowe, 2011) unless runoff is treated.

Studies have revealed green roofs to be both sources of water contaminants, as well as sinks. Berndtsson et al. (2006) found extensive sedum-moss roofs to be a source of pollutants such as $\mathrm{Cd}$, $\mathrm{Cr}, \mathrm{Cu}, \mathrm{Fe}, \mathrm{K}, \mathrm{Mn}, \mathrm{Pb}, \mathrm{Zn}, \mathrm{NO}_{3}{ }^{-}$and $\mathrm{PO}_{4}{ }^{3-}$ when compared to a nonvegetated roof. However, it was concluded that the overall runoff 
quality can be considered good in relation to water quality standards. Mendez et al. (2011) found elevated As and high Pb in the first flush of an extensive green roof. The green roof substrate itself can be a source of metals, as was found in a study with different commercial soil assemblages based on either clay and peat mixtures or inorganic volcanic material and compost. Significant quantities of $\mathrm{Fe}$ and $\mathrm{Al}$ were leached from some substrate types and considerable quantities of $\mathrm{Cu}$ from another (Vijayaraghavan et al., 2012). Most studies, however, find no substantial release of heavy metals from green roofs. A comparison of a Swedish extensive roof with an intensive roof in Japan found neither roof to be a great source of metals (Berndtsson et al., 2009). One of the first studies to investigate green roof runoff quality found percentage retention of contaminant influx to be $95 \%$ for $\mathrm{Pb}$ and $88 \%$ for Cd (Köhler et al., 2002). Metal concentrations found in green roof runoff are generally similar to those in precipitation, and consequently, when the reduced quantity of runoff by green roofs is taken into consideration, the net effect is of a reduced metal flux (Berndtsson, 2010). Concentrations of heavy metals in runoff coming from different urban surfaces, including tiles, concrete and copper roofs, revealed green roofs to have the lowest amount of metals, except for $\mathrm{Zn}$ (Göbel et al., 2007). Green roofs also generally act to mitigate mild acid rain by raising the pH from between to 5 to 6 in rainfall to between 7 and 8 (Berndtsson, 2010).

The most common impact on green roof runoff quality comes from $\mathrm{N}$ and $\mathrm{P}$. High nutrients have been frequently found in green roof runoff (Vijayaraghavan et al., 2012; Gregoire and Clausen, 2011; Teemusk and Mander, 2007; Monterusso et al., 2004) with the $\mathrm{N}$ and $\mathrm{P}$ amounts being directly related to organic matter content (Moran et al., 2003). Additionally, the use of artificial fertilisers on green roofs is a major source of nutrients. Emilsson et al. (2007) demonstrated how conventional fertilisers cause high nutrient concentrations in the runoff, and this was influenced by not only the vegetation system type, but by the age of the vegetation mat. Old mats reduced the risk of nutrient leaching, potentially due to temporary storage in the substrate and enhanced uptake by the well-established vegetation. Consequently, reduced application of fertilisers is often suggested by authors to reduce the nutrient concentrations in green roof runoff (Emilsson et al., 2007; Teemusk and Mander, 2011). Dissolved Organic Carbon (DOC) has also been found to be high in green roof runoff due to the presence of organic material (Mentens et al., 2006; Berndtsson et al., 2009). This can be an issue because the discolouration can be problematic in situations where runoff is collected for re-use (Berghage et al., 2007), and concentrations of DOC over $8 \mathrm{mg} \mathrm{l}^{-1}$ can produce disinfection by-products which may then require post-disinfection treatment under US legislation (Mendez et al., 2011).

There are a number of factors which can influence the green roof runoff quality such as the volume of rainfall, local pollution sources, plant selection, and substrate composition (Rowe, 2011). $\mathrm{NO}_{3}{ }^{-}$ concentrations were found to be higher in runoff from a sedum roof in comparison to herbaceous perennials, and in runoff from shallower substrates (Monterusso et al., 2004). The age of the green roof can have an effect on whether the roof behaves as a source or a sink of contaminants. Köhler et al. (2002) found retention of $\mathrm{PO}_{4}{ }^{3-}$ increased from $26 \%$ in the first year to $80 \%$ in the fourth year of monitoring of an extensive green roof. Similarly Berndtsson et al. (2006) stated that $\mathrm{PO}_{4}{ }^{3-}$ release was not a problem on mature roofs. The age of the roof can affect the hydrological conductivity (Getter et al., 2007) and also the contaminant retention due to uptake by the well established vegetation. Conversely one might also expect saturation of contaminants. For instance, shallow soils can quickly become sites of significant $\mathrm{N}$ leaching as a result of high atmospheric inputs and limited retention capacity (Dise and Wright, 1995).
Green roofs are a relatively new technology in the UK, thus studies on aged green roofs are scarce. A benefit of such a study would be to reveal how older green roofs influence runoff water quality and consequently to see if both contemporary and historic loadings of metals in an urban environment significantly impact on this quality. Although many green roofs are now being established in relatively clean environments, this is not the case everywhere. Installation of green roofs in polluted areas as part of an air quality management strategy needs to be guided by an awareness of the issue of legacy pollutants so that suitable recommendations can be issued. There is evidence of legacy inputs affecting water quality in other environments, such as $\mathrm{N}$ input to forest ecosystems from chronic atmospheric $\mathrm{N}$ deposition exceeding assimilation capacity and resulting in enhanced export of dissolved inorganic $\mathrm{N}$ in runoff (Dise et al., 1998). Soils contaminated by historical metal mining or past atmospheric metal deposition can also influence surface water quality (Rothwell et al., 2008; Mayes et al., 2010). Extensive roofs, by definition, have substrates less than $150 \mathrm{~mm}$ and there are engineering limits to how deep the soil layer of intensive roofs can be due to the load bearing capacity of buildings. These shallow substrates, positioned within urban environments, have the potential to become saturated with dry and wet deposited pollutants over time. Fine fractions of Road Deposited Sediment (RDS) can also be carried on winds ultimately settling on rooftops, and RDS can frequently be highly contaminated with heavy metals such as $\mathrm{Pb}$ (Taylor and Robertson, 2009). The main sources of $\mathrm{Pb}$ in urban centres historically are from leaded petrol use in vehicles and industries handling materials that bear Pb (Del Rio-Salas et al., 2012). While the use of leaded petrol in UK has been phased out since $1985, \mathrm{~Pb}$ can persist in soils due to its long residence time (Tijhuis et al., 2002). Studies in Manchester have found high Pb levels in RDS several years after the phase-out of leaded petrol, especially in the finer fractions (Robertson and Taylor, 2007). Thus urban soils in Manchester, and possibly old inner city green roofs, are likely to contain elevated $\mathrm{Pb}$, as well as other metals associated with urban anthropogenic inputs, such as $\mathrm{Cu}, \mathrm{Mn}$ and $\mathrm{Zn}$ (Robertson et al., 2003).

There is an ongoing need for quantitative assessments of the impacts of green roofs on water quality, especially if their potential as SUDS is to be promoted. The objective of the current study is to compare the quality of runoff from an aged intensive green roof with that from an adjacent bare roof. The age of the roof, at 43 years, will be a most interesting factor of the study by revealing what impacts age may have on the runoff quality. This will allow the future performance of green roofs to be better estimated.

\section{Methodology}

\subsection{Site description}

Manchester is a large city in north-west England with a population of 498,000 (MCC, 2010).

A green roof within the University of Manchester campus, on the Precinct building, was chosen for the study. The area is classified as open midrise, characterised by a fairly open arrangement of buildings of 3-9 storeys with some trees, typical of an inner city university campus area (Stewart and Oke, 2012). The roof was chosen because it has a conventional roof area $\left(900 \mathrm{~m}^{2}\right)$, consisting of concrete paving slabs, adjacent to a large $\left(408 \mathrm{~m}^{2}\right)$ intensive green roof, which is 43 years old (which has been dated to 1970 on the original blueprints), and has an average depth of $170 \mathrm{~mm}$. The roof is not within rain shadows of any adjacent taller buildings. Fig. 1 shows cross sectional representations of the two study roofs. The green roof is of fairly standard construction with the vegetation and substrate layers divided from the 'egg box' design plastic 


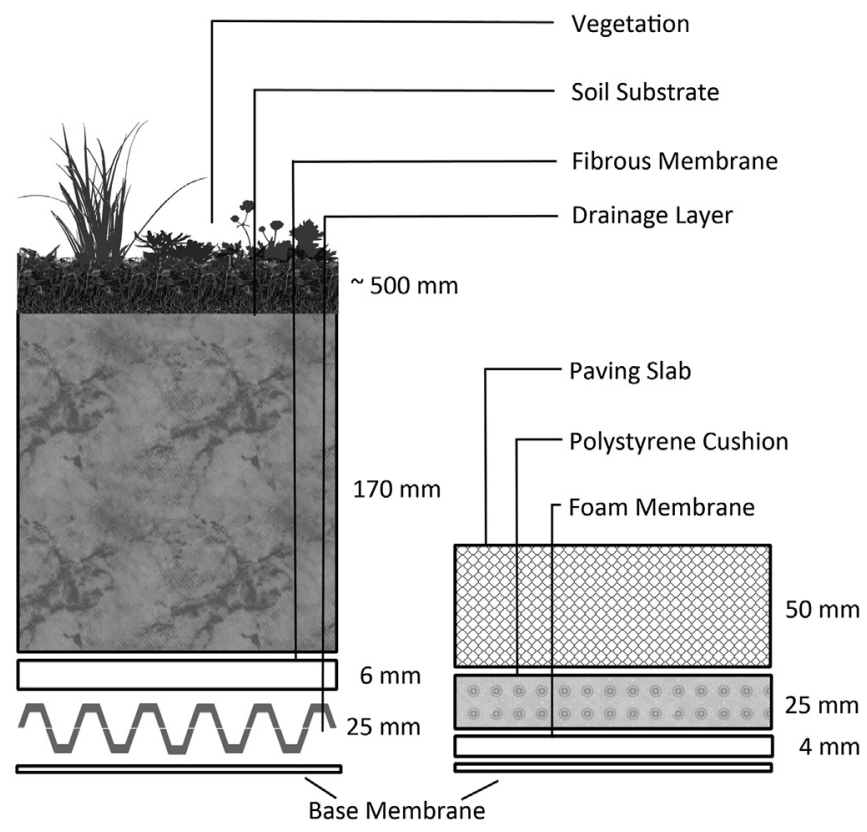

Fig. 1. Cross section of the green roof (left) and bare roof (right) showing layer depths.

drainage layer by a fibrous membrane. Both roofs are protected by a tough geotextile membrane. The bare roof is a conventional roof surface consisting of concrete paving. The $60 \times 60 \mathrm{~cm}$ paving slabs sit on top of an insulating polystyrene cushion and a plastic foam membrane that are impermeable to water.

The green roof is of particular interest due to its age, the fact that the roof was not constructed specifically for the study, and due to it having a mineral soil substrate rather than the more usual, prefabricated, light weight aggregate (LWA) based substrate. Green roof studies with an experimental component often use specially constructed extensive green roof test rigs. While offering a certain degree of control over variables of interest, artificial experimentation studies can overestimate the benefits. For instance, test rigs are often $100 \%$ green coverage, whereas in reality green roofs often have quite high proportions of conventional roof surface, at the periphery, or to provide access for maintenance. Investigating a well established, real green roof which is subject to local weather patterns, will reveal green roof characteristics that can be sensibly applied to the real world.

Building managers were consulted and it was ascertained that no additions of artificial fertilisers or fresh soil had been carried out since 1994, when it was last landscaped. The vegetation on the green roof is dominated by the grasses Agrostis stolonifera and Festuca rubra, and the invasive weed Plantago lanceolata.
Vegetation covers approximately $70 \%$ of the catchment area surface. In summer the vegetation can reach considerable heights, especially the flowering shrub Senecio jacobaea which covers about $20 \%$ of the green roof and grows to a height of $60 \mathrm{~cm}$. There are a few individuals of larger plants - Buddleja davidii and Rubus fruticosus in the southern part of the roof.

\subsection{Sample collection and analysis}

Ten rainfall events were sampled between May and October 2012, seven of which were classed as full event sampling and three events (D1-D3) were sampled as spot monitoring during a wet period in July 2012. See Table 1 for descriptions of the rain events. The number of rain events sampled is similar to previous work (Berndtsson et al., 2006; Mendez et al., 2011). Rain events are defined as being separated by a dry period of at least $6 \mathrm{~h}$ in accordance with previous green roof hydrological research (Stovin et al., 2012). Rainfall depth and duration were recorded, as well as the Antecedent Dry Weather Period (ADWP). Square plastic pots were constructed to sit in the top of two drainage downpipes that have a diameter of $150 \mathrm{~mm}$ - one draining the green roof section and one draining the adjacent conventional roof section (Fig. 2). Runoff entering the drains was channelled into the pots using specially constructed plastic collars fixed into the drain openings with waterproof sealant, and water could then leave the pots via a $60^{\circ} \mathrm{v}$-notch cut into one side. $100 \mathrm{ml}$ of runoff were manually collected from the pots in plastic sample bottles. Samples were collected as near to the start of runoff commencement as possible, and then at $10 \mathrm{~min}$ intervals, until the runoff started to diminish once peak runoff flow was reached. Sampling frequencies were then reduced to every 20 min or every hour, depending on flow rate. This meant that some longer rain events generated a larger number of samples than other events. Approximately $20 \%$ of the area of the both roof catchments is taken up by a glass atrium roof (Fig. 2). For the green roof, this means that a proportion of the runoff will be attributable to a non-green surface.

Bulk rain samples were collected at the same time as four of the events (Table 1) using a funnel of diameter $310 \mathrm{~mm}$ which had been thoroughly rinsed with de-ionised water. Rainfall data were obtained from the Whitworth Observatory (UoM, 2012), situated $150 \mathrm{~m}$ from the precinct roof, which employs a Theis laser distrometer, with an accuracy of $>90 \%$ and resolution of $0.001 \mathrm{~mm} \mathrm{~h}^{-1}$.

Water samples were promptly taken to the laboratory and filtered using $0.45 \mu \mathrm{m}$ syringe filters (VWR cellulose acetate). Subsamples of $20 \mathrm{ml}$ were acidified with high purity nitric acid, to stabilise the samples before analysis for metal ions using ICP-MS (Agilent $7500 \mathrm{cx}$ ). All samples were then stored in a refrigerator in the dark ready for analysis which in all cases was carried out within a week of collection. Benchtop meters were used to measure the $\mathrm{pH}$

Table 1

Characteristics of the rainfall-runoff events sampled.

\begin{tabular}{|c|c|c|c|c|c|c|c|c|c|c|}
\hline \multirow[t]{2}{*}{ Event } & \multirow[t]{2}{*}{ Date } & \multirow{2}{*}{$\begin{array}{l}\text { Rainfall } \\
(\mathrm{mm})\end{array}$} & \multirow{2}{*}{$\begin{array}{l}\text { Duration } \\
\text { (hh:mm) }\end{array}$} & \multirow{2}{*}{$\begin{array}{l}\text { ADWP } \\
\text { (hh:mm) }\end{array}$} & \multirow{2}{*}{$\begin{array}{l}\text { No. of samples } \\
\text { from each roof }\end{array}$} & \multirow[t]{2}{*}{ Rain collected $^{a}$} & \multicolumn{2}{|c|}{ Volume runoff (l) } & \multicolumn{2}{|c|}{ Runoff retention (\%) } \\
\hline & & & & & & & Green roof & Bare roof & Green roof & Bare roof \\
\hline A & $07 / 05 / 2012$ & 0.32 & 01:30 & $68: 10$ & 5 & & 1530 & 1665 & 54 & 15 \\
\hline B & 07/06/2012 & 5.3 & $11: 00$ & 08:00 & 3 & & 775 & 790 & 62 & 35 \\
\hline $\mathrm{C}$ & $15 / 06 / 2012$ & 12.76 & $10: 20$ & $06: 10$ & 13 & Yes $\times 2$ & 1875 & 1895 & 62 & 35 \\
\hline D1 & 06/07/2012 & 22.3 & $11: 30$ & $08: 40$ & 1 & & & & & \\
\hline D2 & $10 / 07 / 2012$ & 5.44 & $17: 30$ & $06: 10$ & 2 & Yes & & & & \\
\hline D3 & $11 / 07 / 2012$ & 1.23 & 04:10 & 09:00 & 1 & & & & & \\
\hline $\mathrm{E}$ & $15 / 08 / 2012$ & 13.31 & $05: 20$ & $64: 50$ & 14 & Yes $\times 2$ & 1635 & 2130 & 68 & 30 \\
\hline $\mathrm{F}$ & $21 / 08 / 2012$ & 1.34 & 03:40 & $30: 00$ & 4 & & 150 & 210 & 70 & 30 \\
\hline G & $10 / 09 / 2012$ & 17.45 & $10: 40$ & $05: 10$ & 12 & & 2665 & 2670 & 69 & 33 \\
\hline $\mathrm{H}$ & $11 / 10 / 2012$ & 21 & $12: 50$ & $15: 10$ & 7 & Yes & 3305 & 3300 & 74 & 31 \\
\hline
\end{tabular}

a Indicates collection of rainfall via funnel. 


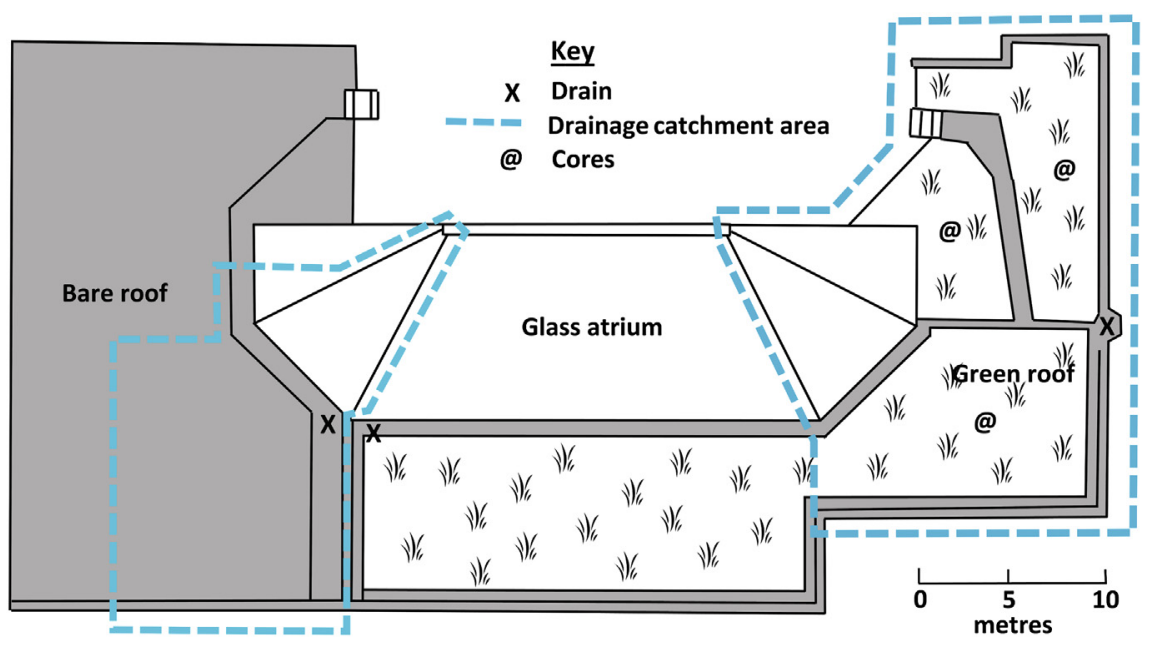

Fig. 2. Plan of the Precinct roof showing drainage catchment areas for the bare and green roofs.

(Hanna HI9124) and conductivity (Hanna HI9033). Anions were measured using ion chromatography in accordance with US EPA method 300 (Metrohm 882 Compact IC plus) and the analytes consisted of $\mathrm{Cl}^{-}, \mathrm{NO}_{3}{ }^{-}, \mathrm{PO}_{4}{ }^{3-}$ and $\mathrm{SO}_{4}{ }^{2-}$. Visible light absorbance over the wavelength range $190-700 \mathrm{~nm}$ was recorded using a spectrophotometer (Hach Lange DR5000). Absorbance at $400 \mathrm{~nm}$ can be used as a proxy for Dissolved Organic Carbon (DOC) in accordance with other work (Wallage et al., 2006). The ratio of the absorbance at $465 \mathrm{~nm}$ and $665 \mathrm{~nm}$, also known as the $\mathrm{E}_{4} / \mathrm{E}_{6}$ ratio, can give an indication of the nature of the DOC, with ratios of 8-17 indicating fulvic acids and 2-5 characteristic of humic material (Wallage et al., 2006).

A representative number of samples of the substrate layer were collected and analysed in a laboratory to determine the following physical parameters: soil texture (particle size analysis), field capacity (Buchner funnel method); dry bulk density (cylinder sampling method); porosity (from bulk density and particle density); and organic matter content (loss on ignition). A Guelph permeameter was employed on the green roof to determine the saturated hydrologic conductivity, a measure of permeability. Twelve extra soil samples were taken from the surface of the green roof, with the sampling locations maximally spaced over the green roof. These samples were analysed in a laboratory to determine $\mathrm{pH}$, conductivity, and water soluble $\mathrm{Cl}^{-}, \mathrm{NO}_{3}{ }^{-}, \mathrm{NO}_{2}{ }^{-}, \mathrm{PO}_{4}{ }^{3-}$ and $\mathrm{SO}_{4}{ }^{2-}$. On the bare roof, it was observed that substantial accumulations of dust were located underneath the paving slabs. Four samples of this dust were collected. The soil and dust samples were dried at $40{ }^{\circ} \mathrm{C}$ and sieved to $125 \mu \mathrm{m}$ to remove stones/twigs/leaves and homogenised in a ball grinder (Fritsch Spartan pulverisette 0) and then analysed for metals using X-ray fluorescence (XRF) in accordance with US EPA method 6200. Each sample was analysed three times with a Niton XL3t XRF analyser. Three $40 \mathrm{~mm}$ diameter cores of the full substrate depth were taken from central areas of the green roof sections (Fig. 2). These were split into ten equal fractions, prepared as described above, and analysed separately using XRF to provide a depth profile of soil elements.

Soil geochemistry data for Manchester city centre were made available by the British Geological Survey (BGS) Geochemical Baseline Survey of the Environment (G-BASE) project which aims to provide a national capability for geochemical mapping (Johnson et al., 2005). Composites are made from five surface samples $(0.05-0.20 \mathrm{~m})$ within a $20 \mathrm{~m} \times 20 \mathrm{~m}$ square, and analysed using XRF (Fordyce et al., 2005). 55 data points were used to produce geochemical maps using ordinary kriging techniques in Arc-Map utilising a box-cox transformation to normalise data. The Environmental Quality Standards (EQS) for surface water quality under directive 2000/60/EC of the Water Framework Directive were obtained from the UK Environment Agency (EA, 2011).

\subsection{Data analysis}

Runoff quantity and retention data were available for three of the fully sampled events, C, E and H (Table 1), and this was used to estimate fluxes of the analytes by calculating the product of the average event concentration and the total runoff volume for both roofs. The runoff quantity data were also used to investigate the presence of a first flush in the events by using mass/volume relationships (Kaczala et al., 2011). Only event E was found to have a significant first flush and these higher concentrations were excluded when calculating averages and undertaking analysis. This event was the only one to exhibit first flush, possibly for two reasons - event $\mathrm{E}$ had one of the largest ADWP of all the events (Table 1) so there would have been a relatively larger accumulation of dry deposited material on this roof, and the nature of the manual sampling technique meant that the first few minutes of runoff in other events may have been missed while preparing equipment at the onset of rain.

Data were checked for normality using the Anderson Darling test and found to be not normal. Sampling data were pooled for comparison of median values using the Kruskal-Wallis nonparametric statistical test with concentration as the independent variable. The three groups, Green Roof $(N=60)$, Bare Roof $(N=59)$ and Rain $(N=6)$, were classed as independent. All statistical investigations were carried out using $\mathrm{R}$ (version 2.11.1).

\section{Results}

The weather during the study period was unusually wet. $52 \%$ of the days had rain and July 2012 had over double the average amount of rain, calculated as the climate average for 1981-2010. The maximum ADWP for the studied rainfall events was just under three days.

\subsection{Substrate properties}

Table 2 shows the soil characteristics and, where possible, a comparison to the Forschungsgesellschaft Landschaftsentwicklung Landschaftsbau (FLL) guidelines for an intensive green roof (FLL, 
Table 2

Selected soil characteristics and comparison to the FLL guideline values for an intensive green roof.

\begin{tabular}{|c|c|c|c|c|c|c|c|c|c|c|c|c|}
\hline & $\begin{array}{l}\text { Permeability } \\
(\mathrm{cm} / \mathrm{sec})\end{array}$ & $\mathrm{pH}$ & $\begin{array}{l}\text { Field capacity } \\
\text { (max water } \\
\text { capacity } \\
\text { for FLL) }\end{array}$ & $\begin{array}{l}\text { Bulk density } \\
\mathrm{g} \mathrm{cm}^{-3}\end{array}$ & $\begin{array}{l}\text { Particle } \\
\text { density } \\
\mathrm{g} \mathrm{cm}^{-3}\end{array}$ & Porosity $(\theta)$ & $\begin{array}{l}\text { Organic } \\
\text { content } \mathrm{g} \mathrm{l}^{-1}\end{array}$ & $\begin{array}{l}\mathrm{Cl}^{-} \\
\mathrm{mg} \mathrm{kg}^{-1}\end{array}$ & $\begin{array}{l}\mathrm{NO}_{2}^{-} \\
\mathrm{mg} \mathrm{kg}^{-1}\end{array}$ & $\begin{array}{l}\mathrm{NO}_{3}^{-} \\
\mathrm{mg} \mathrm{kg}^{-1}\end{array}$ & $\begin{array}{l}\mathrm{PO}_{4}^{3-} \\
\mathrm{mg} \mathrm{kg}^{-1}\end{array}$ & $\begin{array}{l}\mathrm{SO}_{4}{ }^{2-} \\
\mathrm{mg} \mathrm{kg}^{-1}\end{array}$ \\
\hline Green roof & $1.68 \times 10^{-3}$ & 6.5 & $38 \%$ & 1.03 & 2.47 & 0.58 & 202.54 & 77.9 & 2.49 & 50.84 & 3.35 & 8.51 \\
\hline $\begin{array}{l}\text { FLL guideline } \\
\text { value }\end{array}$ & $5 \times 10^{-4}$ & $6-8.5$ & $45-65 \%$ & - & - & - & $<90$ & - & - & - & - & - \\
\hline
\end{tabular}

2008). For a full summary of the physical soil properties see Speak et al. (2013). The soil is a sandy loam, with quite high organic matter content. Soil chloride levels were comparable to those from a low impact roadside plot (Goodrich et al., 2009). The water-extractable soil nutrient levels are average for a mineral soil (Sumner, 2000). Fig. 3 shows the depth profiles for three of the more important elements and no depth-concentration relationship is apparent within the substrate layer.

The concentrations of selected elements are presented in Table 3, along with the UK ambient background soil concentrations for comparison (Barraclough, 2007). The mean and median elemental concentrations are consistently higher in the bare roof dust than in the green roof substrate. However, the range of values is wider on the green roof, for all elements with the exception of $\mathrm{Zn}$. The mean concentrations for both green roof soil and bare roof dusts are higher than the mean background concentration, and also higher than the 95th percentile background value in the case of As, $\mathrm{Cr}, \mathrm{Cu}$ and $\mathrm{Pb}$. The only exception is $\mathrm{Mn}$ in the green roof substrate which has a lower mean than the background. UK Contaminated Land Exposure Assessment (CLEA) Soil Guideline Values (SGVs) were not exceeded for $\mathrm{Cr}$. Mean $\mathrm{Pb}$ values in the bare roof dust exceeded the SGVs for residential use and some upper values exceeded the SGVs for commercial use. Levels of As in the dust exceed SGVs for residential soil use but fall below the commercial use guidelines. The green roof substrate only exceeded the residential SGVs for $\mathrm{Pb}$ in the upper range of results. The G-BASE data revealed a location of very high metals within the University campus, close to the green roof. Fig. 4 shows spatial distributions of $\mathrm{Cd}, \mathrm{Cu}, \mathrm{Pb}$ and $\mathrm{Zn}$. Average Standard Error (ASE) values for $\mathrm{Cd}, \mathrm{Cu}, \mathrm{Pb}$ and $\mathrm{Zn}$ were $0.6,121.5,246.5$ and $290.5 \mathrm{mg} \mathrm{kg}^{-1}$ respectively. For all the metals there are elevated soil concentrations to the south and east of the studied area, with a very obvious hot spot within the University campus. The precinct roof is located very close to this area of high metals. Exploratory data analysis was undertaken by removing the hot spot data point with extreme values, and the trend of higher metals around the University campus and to the South West of the city centre persisted.

\subsection{Water chemistry}

Firstly $\mathrm{pH}$ and conductivity were significantly lower in the rainwater than in either of the roof runoffs ( $\mathrm{pH}$ Kruskal Wallis $X^{2}=13.4, p<0.001$, conductivity $\left.X^{2}=15.9, p<0.001\right)$. Green roof runoff displayed higher $\mathrm{Fe}$ and $\mathrm{Pb}$ concentrations than the bare roof runoff and rainwater (Fig. 5). The differences were highly significant for both $\mathrm{Fe}\left(X^{2}=76.1, p<0.001\right)$ and $\mathrm{Pb}\left(X^{2}=31.2, p<0.001\right)$. Rainwater was significantly higher in $\mathrm{Cu}\left(X^{2}=36.6, p<0.001\right)$ and $\mathrm{Zn}\left(X^{2}=71.4, p<0.001\right)$ than in the runoff from either roof, and also higher for $\mathrm{Cd}$ and $\mathrm{Ni}$, however the differences for the latter two were minimal. There were also no significant differences in the levels of $\mathrm{Cr}$ and $\mathrm{Mn}$ between the roof runoffs and rainwater.

The fluxes of metals are presented in Table 4. A percentage flux, relative to rainfall, of greater than $100 \%$ indicates the roof is acting as a source of the contaminant. Both roofs therefore appear to act as sinks of the metals, with the exception of $\mathrm{Pb}$, which displayed very high enrichment factors in the runoff of both roofs over the rainfall. Event $\mathrm{E}$ also showed the green roof to be a potential source of $\mathrm{Cr}$.

There were no significant differences in $\mathrm{Cl}^{-}, \mathrm{PO}_{4}{ }^{3-}$ or $\mathrm{SO}_{4}{ }^{2-}$ between the roofs or between the roofs and rainwater. $\mathrm{NO}_{3}{ }^{-}$levels were higher in the bare roof runoff than in the green roof runoff and rainwater and this difference was significant $\left(X^{2}=25.5, p<0.001\right)$. A post hoc test (Mann-Whitney with Bonferroni correction) shows the major difference exists between the two roof runoffs, as opposed to rain and runoffs. The $\mathrm{NO}_{3}{ }^{-}$levels are below $50 \mathrm{mg} \mathrm{l}^{-1}$, which is the upper limit for surface freshwaters with regards to eutrophication threat (EA, 2012). Some of the higher recorded values for $\mathrm{PO}_{4}{ }^{3-}$ exceed the environmental standards of waters classified as poor i.e. $0.5 \mathrm{mg} \mathrm{l}^{-1}$ (DEFRA, 2010) but just over half of the data (54\% for bare roof runoff and $53 \%$ for green roof runoff), and the median, were below the detection limit. The fluxes in
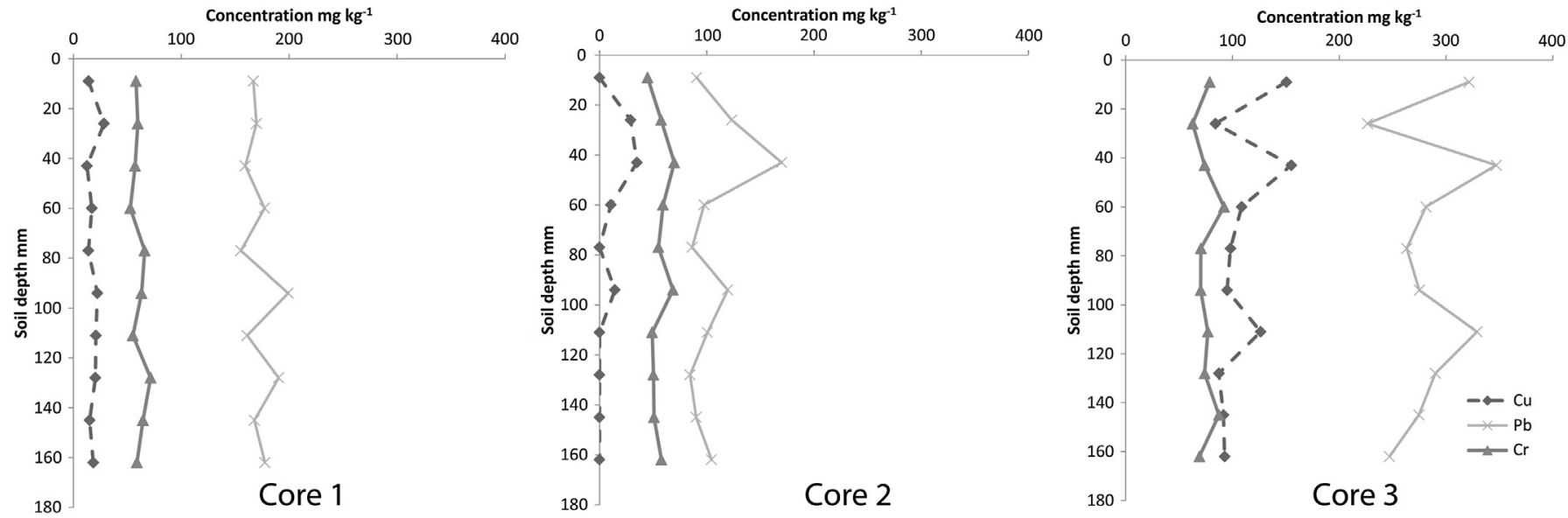

Fig. 3. Vertical soil profiles for $\mathrm{Cu}, \mathrm{Pb}$ and $\mathrm{Cr}$ in the intensive green roof. 
Table 3

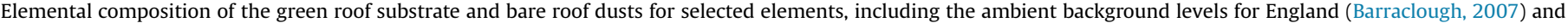
CLEA Soil Guideline Values (SGVs), where available, for comparison.

\begin{tabular}{|c|c|c|c|c|c|c|c|c|}
\hline & & \multicolumn{7}{|c|}{ Concentration $\mathrm{mg} \mathrm{kg}^{-1}$} \\
\hline & & As & $\mathrm{Cr}$ & $\mathrm{Cu}$ & $\mathrm{Fe}$ & Mn & $\mathrm{Pb}$ & $\mathrm{Zn}$ \\
\hline \multirow[t]{3}{*}{ Green roof substrate $(n=36)$} & Median & 23.3 & 67.2 & 17 & 21,188 & 245 & 105 & 126 \\
\hline & Mean & 33.7 & 76.5 & 45.7 & 25,575 & 313 & 164 & 160 \\
\hline & Range & $13.4-90.2$ & $49-118$ & 0-195 & $11,070-53,077$ & $164-638$ & $59-463$ & $66.5-402$ \\
\hline \multirow[t]{3}{*}{ Bare roof dust $(n=12)$} & Median & 46.2 & 142.9 & 171 & 38,058 & 838 & 705 & 1942 \\
\hline & Mean & 47.2 & 144 & 182 & 38,252 & 834 & 691 & 2401 \\
\hline & Range & $43-53.4$ & $126-163$ & $124-262$ & $34,928-41,961$ & $719-942$ & $567-789$ & $1347-4375$ \\
\hline \multirow[t]{2}{*}{ UK ambient background } & Mean & 13.9 & 33.4 & 19.8 & - & 615 & 62 & 95 \\
\hline & 95 percentile & 27.1 & 59.5 & 43.3 & - & 1567 & 158 & 224 \\
\hline \multirow[t]{2}{*}{ CLEA SGV } & Residential & 32 & 200 & - & - & - & 450 & - \\
\hline & Commercial & 640 & 5000 & - & - & - & 750 & - \\
\hline
\end{tabular}

Table 4 reveal the bare roof to be more frequently a source of the anions in comparison to rainwater inputs, with $\mathrm{SO}_{4}{ }^{2-}$ being higher than in rainfall for all three events. $\mathrm{PO}_{4}{ }^{3-}$ is always lower than the rainfall input on both roofs and $\mathrm{NO}_{3}{ }^{-}$is lower on the green roof.

The absorbance at $400 \mathrm{~nm}$ is significantly higher on the green roof runoff $\left(X^{2}=69.7, p<0.001\right)$, being approximately double that from the bare roof runoff. A post hoc test shows the major difference is between the two roof runoffs, as opposed to between rain and runoffs. The green roof runoff was observed to have a weak green/yellow colour, and the median value of $3 \mathrm{abs} \mathrm{m}^{-1}$ is double the European Community standard of 1.5 abs $\mathrm{m}^{-1}$ acceptable for drinking water (Mitchell, 1990). The $\mathrm{E}_{4} / \mathrm{E}_{6}$ ratios were consistently low with an average of $3.3(S D=0.89)$ and one high value of 18.5 during the first flush at the start of event $\mathrm{E}$.

\section{Discussion}

\subsection{General runoff characteristics}

The roofs had the effect of slightly raising the $\mathrm{pH}$ of the rainwater, which is likely a result of the effect of dissolved solutes picked up on the roof. This buffering effect on slightly acidic rain is common (Teemusk and Mander, 2011). Berghage et al. (2007) recommend artificial liming of green roofs after 10-30 years because the $\mathrm{pH}$ buffering effect is predicted to diminish. This was not apparent on the 43 year old roof in the present study. The conductivity is raised by roughly $50 \mu \mathrm{S} \mathrm{cm}^{-1}$ on each roof relative to the rainfall conductivity as a result of the increase in dissolved ion content (Fig. 5).

A source of $\mathrm{PO}_{4}{ }^{3-}$ and $\mathrm{SO}_{4}{ }^{2-}$ may be present on both roofs giving rise to the higher concentrations found (Fig. 5) and the high fluxes of $\mathrm{SO}_{4}{ }^{2-}$ for some events (Table 4). The $\mathrm{SO}_{4}{ }^{2-}$ values are much lower than in previous studies, however (Teemusk and Mander, 2007; Vijayaraghavan et al., 2012). $\mathrm{PO}_{4}{ }^{3-}$ values are also lower than some published values (Beck et al., 2011; Vijayaraghavan et al., 2012) but may potentially contribute to eutrophication. However, this threat may not be regarded as severe due to the fact that just over half the data were below the detection limit. There are no sources from artificial fertilisers on the green roof and older roofs tend to generate less $\mathrm{PO}_{4}{ }^{3-}$ runoff consistent with Emilsson et al. (2007).

Lower $\mathrm{NO}_{3}{ }^{-}$in the green roof runoff compared to the bare roof could be due to being scavenged by plants. One might expect $\mathrm{N}$
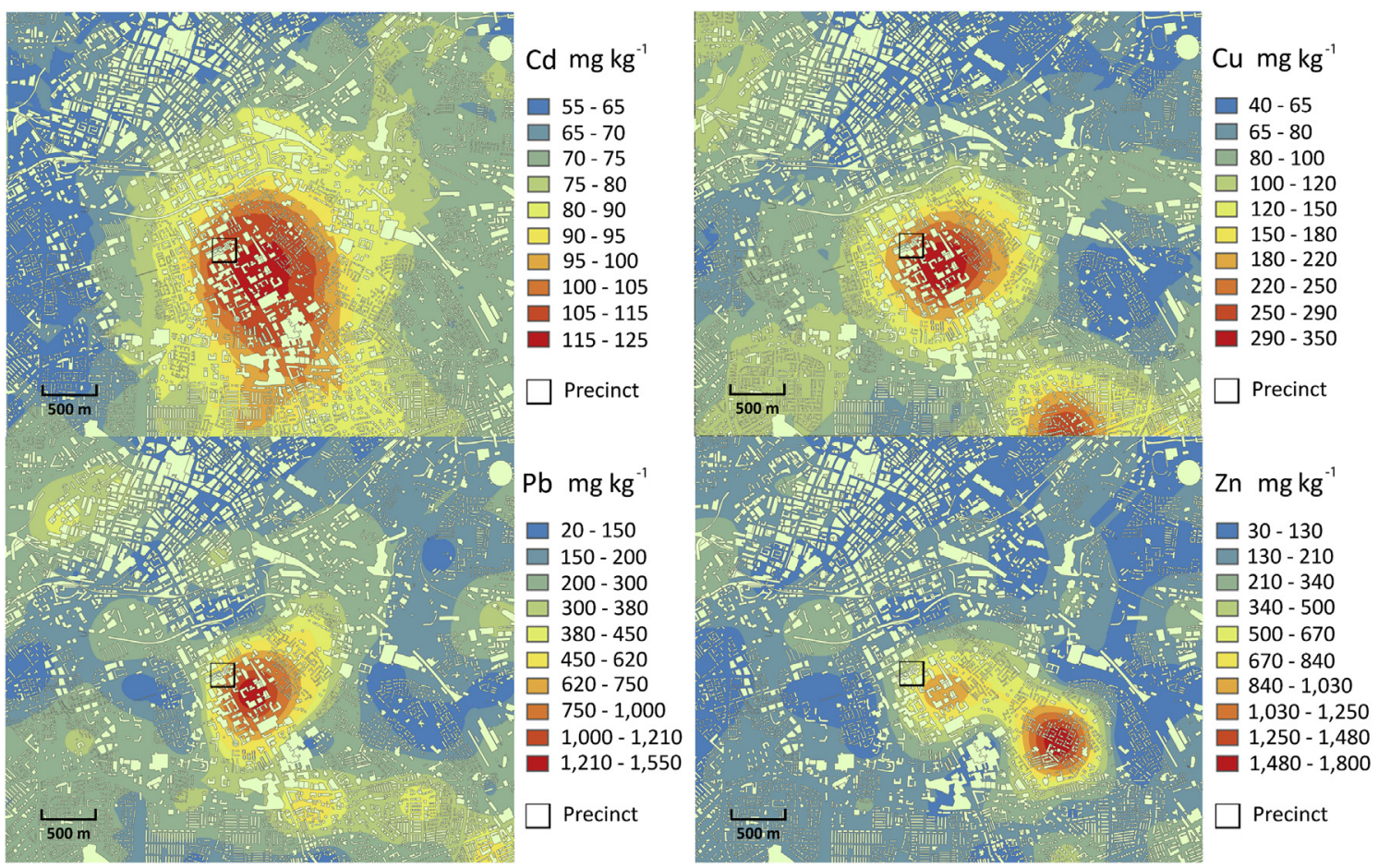

Fig. 4. Spatial distribution of $\mathrm{Pb}, \mathrm{Cd}, \mathrm{Cu}$ and $\mathrm{Zn}$ using ordinary kriging with 55 data points. Source: BGS G-BASE project. 

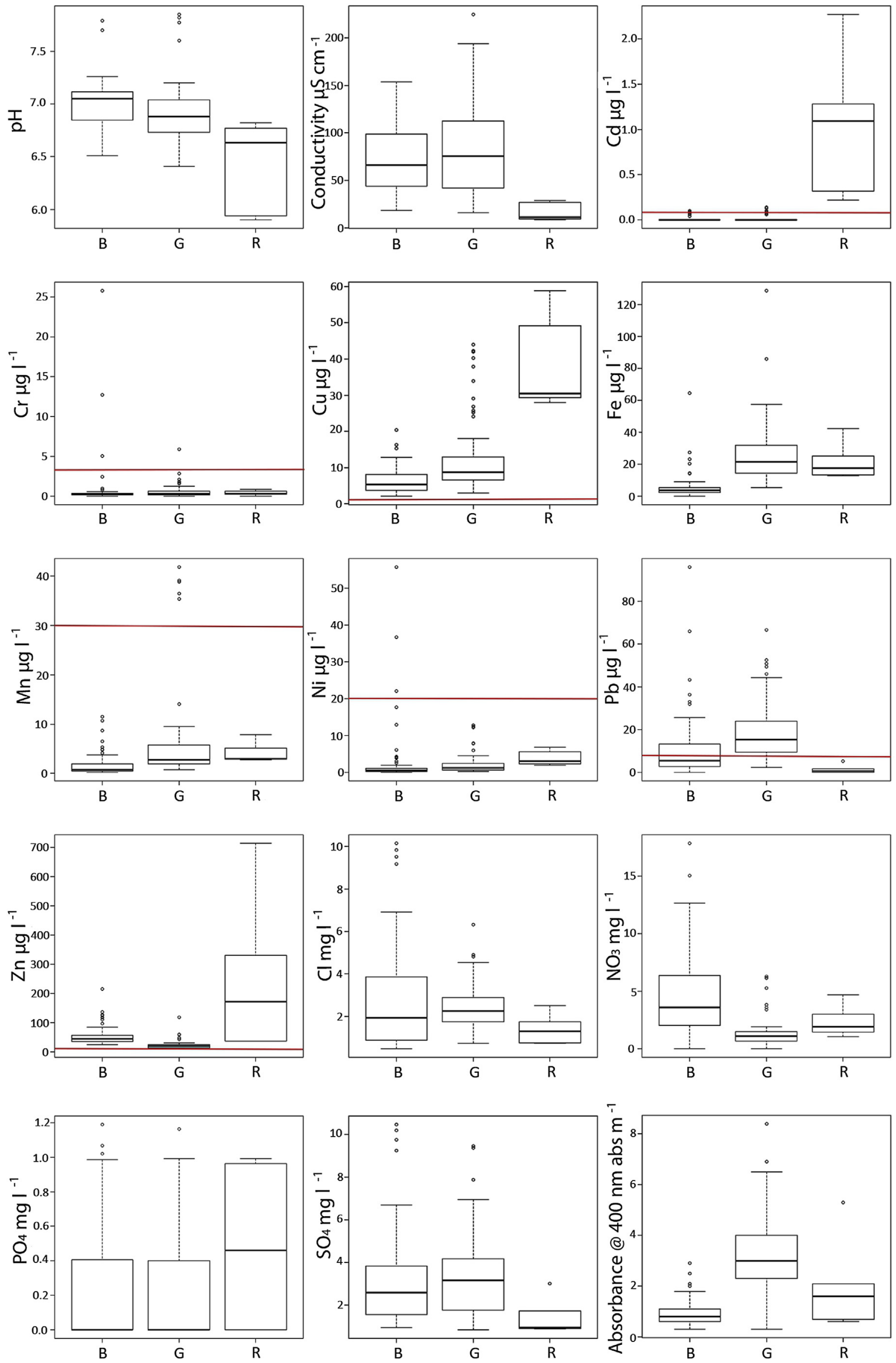

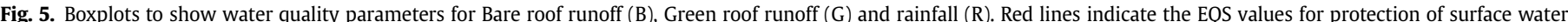
quality. (For interpretation of the references to colour in this figure legend, the reader is referred to the web version of this article.) 
saturation on a limited depth soil after 43 years of receiving atmospheric inputs (Dise and Wright, 1995) but this does not appear to be the case even though annual $\mathrm{N}$ deposition in Manchester in 2011 is moderate at $12-14 \mathrm{~kg} \mathrm{~N} \mathrm{ha}^{-1} \mathrm{yr}^{-1}$ (DEFRA, 2013). Average $\mathrm{NO}_{3}{ }^{-}$levels in rainfall, at $1.9 \mathrm{mg} \mathrm{l^{-1 }}$, were higher than the UK average of $0.35 \mathrm{mg} \mathrm{l}^{-1}$ for the period 1986-2000 (Hayman et al., 2001). This could be an indication of high local sources from fossil fuel combustion (Buss et al., 2005) in vehicles in the city centre.

The higher $\mathrm{Cl}^{-}$concentrations in the roof runoffs than in rainfall, and the indication of the roofs as sources from the flux data, could likely be coming from airborne spread of road salting (Lundmark and Olofsson, 2007) as Manchester is not a coastal city so rainwater inputs will be small. The median rainwater $\mathrm{Cl}^{-}$concentration of $1.3 \mathrm{mg} \mathrm{l}^{-1}$ is at the lower end of the range of values of $0.4-$ $3000 \mathrm{mg} \mathrm{l}^{-1}$ for rainfall in England (White and Broadley, 2001). The green roof is also a further distance from Oxford Road, and the study took place mostly over the summer when road salting was not occurring. Soil water soluble $\mathrm{Cl}^{-}$values for roadsides in Poland varied from 40 to $150 \mathrm{mg} \mathrm{kg}^{-1}$ (Czerniawska-Kusza et al., 2004) so the present study values are comparable.

The absorbance data suggest there is higher DOC in the green roof runoff, most likely from the soil organic matter. The $\mathrm{E}_{4} / \mathrm{E}_{6}$ ratios reveal this to be mostly humic in nature (Wallage et al., 2006) with a brief pulse of younger fulvic acids in the first flush of event $E$ which could be coming from fresh leaf litter on the green roof surface or collected in the drainage channel. The water from this roof is not being re-used so colour can be considered to be not an issue.

\subsection{Elevated metal concentrations}

It would appear that dissolved metal concentrations may be an issue for green roof runoff quality for this aged green roof. Median $\mathrm{Cu}, \mathrm{Pb}$ and $\mathrm{Zn}$ all exceed the EQS values for protection of surface water (1, 7.2 and $8 \mu \mathrm{g} \mathrm{l}^{-1}$ respectively) and thus may contribute to UDP. Fluxes, however, indicate both roofs to be sinks, with the major exception of $\mathrm{Pb}$. This could be due to the unusually large rainwater concentrations found in this study, especially for $\mathrm{Cd}, \mathrm{Cu}$ and $\mathrm{Zn}$ (Fig. 5). Cu and Zn levels were comparable to those found in rainfall in a large city in China (Zuo et al., 2012). This may be a result of the small rainwater sample size or high local sources of metals in rain. Rainwater concentrations at the Holme Moss station of the heavy metal monitoring network (Fowler et al., 2006), which is closest to Manchester, recorded $\mathrm{Cd}, \mathrm{Cr}, \mathrm{Cu}, \mathrm{Pb}$ and $\mathrm{Zn}$ levels of 0.04 , $0.23,1.57,2.27$ and $12.2 \mu \mathrm{g} \mathrm{l^{-1 }}$ respectively in 2005 , which further highlights the extreme nature of the rainfall concentrations recorded for $\mathrm{Cd}, \mathrm{Cu}$ and $\mathrm{Zn}$ in this study. In comparison with other studies, green roof runoff values for $\mathrm{Cu}, \mathrm{Cr}, \mathrm{Fe}$ and $\mathrm{Zn}$ are fairly similar to those reported by Berndtsson et al. (2006) on a one year old extensive green roof, and the $\mathrm{Zn}$ values were lower than the $300 \mu \mathrm{g} \mathrm{l} \mathrm{l}^{-1}$ found by Mendez et al. (2011).

The $\mathrm{Pb}$ values deserve further discussion, as the high values in the runoff of both roofs and low values in the rainfall suggest a source of $\mathrm{Pb}$ on the roofs. The highest concentrations were found on the green roof with a median value of $15 \mu \mathrm{g} \mathrm{l^{-1 }}$, which is higher than the $10 \mu \mathrm{g} \mathrm{l}^{-1}$ (Berndtsson et al., 2006) and $4 \mu \mathrm{g} \mathrm{l}^{-1}$ (Mendez et al., 2011) found in previous studies. The indication of a potential source of $\mathrm{Pb}$ in the green roof soil and bare roof dusts is certainly corroborated by the high $\mathrm{Pb}$ values found in the solid phase within the sediments/soils (Table 3). A mean of $164 \mathrm{mg} \mathrm{kg}^{-1}$ on the green roof and $691 \mathrm{mg} \mathrm{kg}^{-1}$ on the bare roof compare well to inner city RDS samples taken from Manchester city centre, which varied seasonally but ranged from 71 to $660 \mathrm{mg} \mathrm{kg}^{-1}$ (Robertson and Taylor, 2007). There is some lead flashing on the atrium roof over which the rainfall can flow, and roof surfaces have been sources of $\mathrm{Pb}$ in previous studies on conventional roof surfaces (Simmons et al., 2001; Rocher et al., 2004). Flashing sometimes gives rise to elevated $\mathrm{Pb}$ (Abbasi and Abbasi, 2011). Rainwater that is acidic or contains high concentrations of $\mathrm{Cl}^{-}$can be plumbosolvent, but rainwater can also reduce corrosion by forming a protective, insoluble coating of $\mathrm{PbCO}_{3}$ (Evans, 1960). Given such high $\mathrm{Pb}$ concentrations in the dust or soil from the roofs it is likely that the majority of the $\mathrm{Pb}$ is being leached from those compartments.

In order to separate the influence of the atrium runoff on $\mathrm{Pb}$ concentrations, atrium runoff was diverted and sampled separately for a heavy rain event. The results in Fig. 6 indicate that both the atrium and the green roof are raising the $\mathrm{Pb}$ concentrations over that of rainfall. The median and range are larger for the atrium, which would suggest the flashing may indeed be a contributing factor; however the values for the whole study are higher for green roof runoff.

To further investigate the dynamics of $\mathrm{Pb}$ on the green roof, a simple input/output model was proposed (Fig. 7). Inputs were calculated from atmospheric deposition data (MacKenzie et al., 1998; Fowler et al., 2006; Cloy et al., 2008) and extrapolations from trends in emissions data (MAPAC, 1993; NAEI, 2013) over the lifetime of the green roof. Present day mean soil concentration and soil bulk density were used to estimate the total amount of $\mathrm{Pb}$ stored within the green roof as $72 \mathrm{~g}$. Present day $\mathrm{Pb}$ output was calculated from the product of runoff volume and present day mean runoff concentration. Total $\mathrm{Pb}$ output (Fig. 7a) is simply total $\mathrm{Pb}$ deposited minus $\mathrm{Pb}$ stored in the soil. Assumptions made are that rainfall retention efficiency is $66 \%$ (Speak et al., 2013), runoff concentration has remained constant over the life of the green roof, and the soil contained negligible $\mathrm{Pb}$ when the green roof was installed. The latter is therefore assuming the soil selected by the constructors came from an uncontaminated source and has become contaminated over the lifetime of the green roof. The present day situation shows there is more $\mathrm{Pb}$ coming out of the roof than is being deposited which implies the green roof soil is acting as a source of $\mathrm{Pb}$. An output of $38 \mathrm{~g}$ over 43 years suggests a rate of $0.88 \mathrm{~g} \mathrm{yr}^{-1}$ which is not too dissimilar to the present day empirically estimated rate of $1.34 \mathrm{~g} \mathrm{yr}^{-1}$, indicating the model has applicability. Keeping present day atmospheric inputs and outputs steady means the green roof would continue to be a source of $\mathrm{Pb}$ for 70 years. The model also includes the contribution of the atrium, with its potential lead flashing source, and it is clear that while

Table 4

Output flux expressed as a percentage of input flux for the three rainfall events where flux calculation was possible. Bold results indicate $>100 \%$.

\begin{tabular}{|c|c|c|c|c|c|c|c|c|c|c|c|c|c|}
\hline Roof & Event & $\mathrm{Cr}$ & $\mathrm{Mn}$ & $\mathrm{Fe}$ & $\mathrm{Ni}$ & $\mathrm{Cu}$ & $\mathrm{Zn}$ & $\mathrm{Cd}$ & $\mathrm{Pb}$ & $\mathrm{Cl}^{-}$ & $\mathrm{NO}_{3}^{-}$ & $\mathrm{PO}_{4}{ }^{3-}$ & $\mathrm{SO}_{4}{ }^{2-}$ \\
\hline \multirow[t]{3}{*}{ Bare } & $C$ & 35.5 & 12.4 & 14.7 & 9.5 & 7.0 & 6.1 & 0.0 & 140.3 & 82.5 & 137.9 & 62.5 & 101.8 \\
\hline & $\mathrm{E}$ & 88.8 & 19.2 & 22.1 & 13.5 & 11.8 & 70.8 & 3.1 & 512.3 & 78.1 & 142.4 & 54.0 & 121.2 \\
\hline & $\mathrm{H}$ & 40.8 & 24.0 & 6.2 & 5.2 & 16.6 & 19.8 & 0.0 & 219.3 & 202.6 & 87.9 & 0.0 & 105.2 \\
\hline \multirow[t]{3}{*}{ Green } & $C$ & 23.6 & 19.9 & 53.9 & 8.4 & 6.4 & 2.0 & 0.0 & 233.9 & 46.7 & 34.0 & 36.0 & 127.0 \\
\hline & $E$ & 134.9 & 27.5 & 51.9 & 21.3 & 11.1 & 16.6 & 3.6 & 734.4 & 128.7 & 64.4 & 24.1 & 97.5 \\
\hline & $\mathrm{H}$ & 16.5 & 16.7 & 12.5 & 3.3 & 8.6 & 1.1 & 0.0 & 69.4 & 64.2 & 23.3 & 0.0 & 35.8 \\
\hline
\end{tabular}




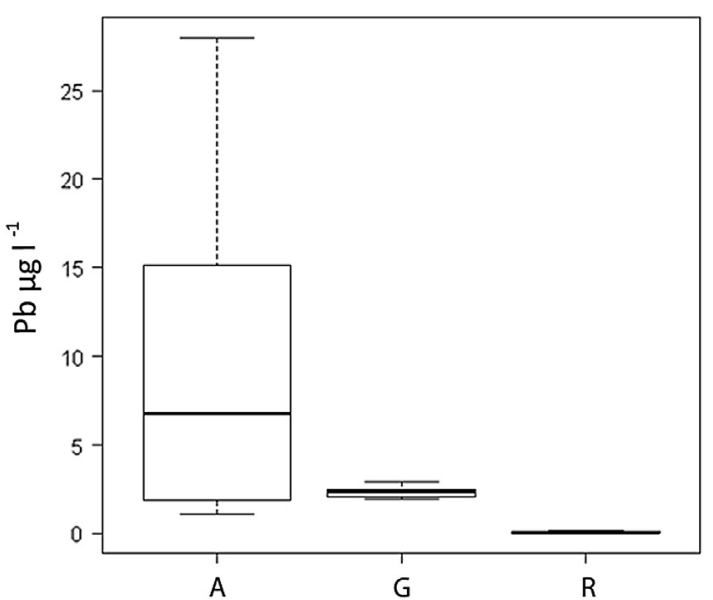

Fig. 6. Boxplot of $\mathrm{Pb}$ concentrations in the runoff from the atrium (A), the green roof $(G)$ and in rainfall $(R)$ for one event.

concentrations are comparable to green roof runoff concentrations, overall mass flux is much lower.

The original source of the $\mathrm{Pb}$ in the substrates is debatable but it is likely a remnant of $\mathrm{Pb}$ pollution from vehicle use prior to the phasing out of leaded petrol in 1985, as contemporary atmospheric deposition is minimal. This is evidenced by the low rainwater concentrations and total $\mathrm{Pb}$ deposition in 2008 in Manchester was 10-15 $\mathrm{g} \mathrm{ha}^{-1} \mathrm{yr}^{-1}$ (DEFRA, 2013) (cf. 50-75 $\mathrm{g} \mathrm{ha}^{-1} \mathrm{yr}^{-1}$ in 19951998 (Fowler et al., 2006)). Both roofs will have received direct atmospheric deposition plus inputs of RDS, carried to the rooftops by winds. The bare roof dusts represent a primary form of the contaminated RDS, whereas it has become somewhat diluted within the green roof soil. While there is a much smaller quantity of sediments under the paving of the bare roof, the high $\mathrm{Pb}$ content is contributing significantly to the runoff concentrations, with just under half the values exceeding the EQS (Fig. 5). The green roof substrate is 43 years old and the original source of the soil is also unknown so it is possible that $\mathrm{Pb}$ may have been high in the soil when it was installed. Depth profiles for the metals were uniform possibly as a result of high bioturbation on the roof. It could be the soil was high in metals to start with, as a result of less stringent guidelines on the quality of soil sources for roof gardens in the 1970s, before FLL guidelines were compiled. However, this does not account for the higher metal concentrations in the dusts on the bare roof.

One other thing to consider is the hot spot of contaminants located very close to the precinct roof (Fig. 4). Soil Pb levels in this

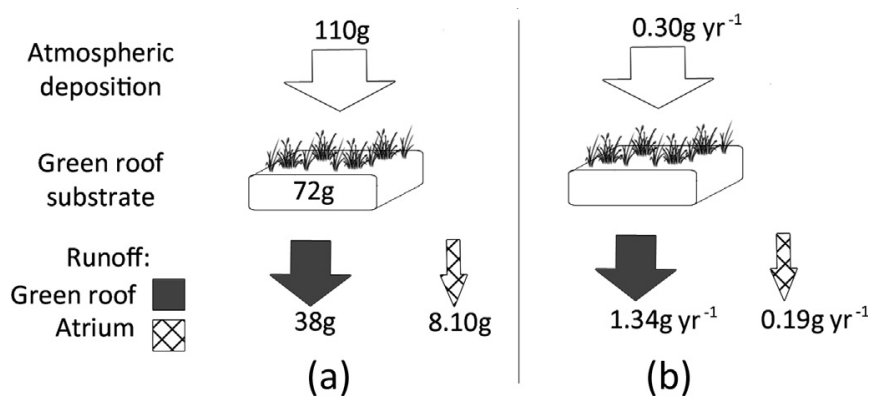

Fig. 7. A model of the atmospheric inputs, stores and outputs of $\mathrm{Pb}$ for (a) the entire life of the green roof and (b) the annual flux based on present-day data. There is currently more $\mathrm{Pb}$ coming out of the roof than is being deposited which implies the green roof is acting as a source of $\mathrm{Pb}$. area exceed the SGVs for commercial use. There is the possibility that some of the contamination on the precinct roof may have arisen from aeolian dust transport of this nearby contaminated topsoil. Resuspended soil has been previously linked to the long distance transport of $\mathrm{Pb}$ (Young et al., 2002). Examination of past industries in the area has not revealed any obvious source for this high contamination.

The soil and dust levels on the precinct roof were quite high for most of the metals, exceeding the 95th percentile values of the UK ambient background survey. The narrower range of contaminants in the bare roof dusts backs up the notion that the green roof soil, with its wider ranges of concentrations, has diluted RDS inputs. The two roofs behaved similarly with respect to runoff concentrations for most contaminants, relative to the rain. The bare roof dusts are much less in quantity than the green roof soil therefore sources of contamination to both roofs might be similar which adds weight to the explanation of atmospheric deposition and Aeolian transport of RDS. However, this is just speculation without further experiments to determine the ultimate sources of the contaminants.

\subsection{Implication of findings}

The discovery of legacy metal contamination of urban soils is not a new phenomenon; however this is possibly the first time it has been found in the soils and runoff from a green roof. Source apportionment (Del Rio-Salas et al., 2012) of the metals found within the green roof substrate and in the bare roof dusts would enable more details about the processes behind the contamination to be revealed. $\mathrm{Pb}$ isotopic analysis (Chiaradia and Cupelin, 2000), for instance, could quantify the contribution of anthropogenic processes to the $\mathrm{Pb}$ enrichment observed in the area and roof sediments and determine whether the green roof soil represents a diluted form of the RDS. Nonetheless the 43 year old green roof is old enough to have been exposed to direct atmospheric inputs as well as post leaded petrol ban inputs from re-suspended RDS. The fact that a green roof can thus potentially contain a store of $\mathrm{Pb}$ pollution must be taken into consideration when constructing contemporary green roofs near to pollution sources. Green roofs are rightly being heralded as remediators of air pollution but if that pollution is accumulating to levels which impact the future runoff quality then problems may ensue. The promotion of green roof runoff for re-use, for instance as a source of potable water, especially needs to be carefully considered.

This study investigated an old intensive green roof with a mineral soil of unknown origin. Modern green roof technologies are currently based on utilising various light weight substrates, such as expanded clay, and consideration is being given to the impact of these upon runoff (Vijayaraghavan et al., 2012). Expanded shale has been found to be good for retention of $\mathrm{P}, \mathrm{NH}_{4}-\mathrm{N}$ and metals (Long et al., 2006). There are also amendments to substrates, such as adding biochar, which can significantly reduce nutrient leaching whilst simultaneously allowing the addition of artificial fertilisers (Beck et al., 2011). This study has shown that the long term performance as regards runoff quality, of these modern substrates, should be at least estimated, or ideally longitudinal monitoring studies commenced. The pollution reduction properties of green roofs in urban areas can then be balanced with improvements in the runoff quality from the substrates.

\section{Conclusion}

Runoff from a green roof and an adjacent conventional roof surface was characterised with regards to heavy metals and nutrients, and linked to soil chemical properties. The study roof is of 
interest because it is an aged intensive green roof. The following findings were made:

- Nutrient levels in the runoff were not problematic for runoff quality, as the roofs appear to be a net sink for $\mathrm{PO}_{4}{ }^{3-}$ in most cases. $\mathrm{NO}_{3}{ }^{-}$levels were also low so the roof did not appear to be saturated with regards to inorganic $\mathrm{N}$, contrary to expectation. Fluxes of nutrients will also be lower in the green roof runoff due to higher runoff retention.

- High concentrations, exceeding the EQS limits for protection of freshwater, of $\mathrm{Cu}, \mathrm{Pb}$ and $\mathrm{Zn}$ were apparent in the green roof runoff. Overall fluxes for three rain events revealed $\mathrm{Pb}$ quantities to be higher in runoff from both the green roof and the bare roof than in rainfall, which suggests the existence of $\mathrm{a} \mathrm{Pb}$ source within their respective sediments. Lead flashing within the rainfall catchments of both roofs may also contribute.

- Metal and metalloid concentrations, specifically $\mathrm{As}, \mathrm{Cr}, \mathrm{Cu}, \mathrm{Fe}$, $\mathrm{Pb}$ and $\mathrm{Zn}$, within these dusts exceeded the 95th percentile values of UK ambient background, thus indicating contamination on both roofs.

- Possible sources of contamination include wind blown Road Deposited Sediment (RDS) which has settled onto the roofs and become diluted within the green roof substrate, and a local area of highly polluted topsoil which may also contribute to wind blown contaminated sediment load on the roofs. Contaminated soil used in the original green roof construction cannot be overlooked, however this would not account for the higher concentrations of contaminants on the bare roof.

- The results of a budget analysis on this 43 year old green roof suggest that historic atmospheric deposition of $\mathrm{Pb}$ could be contributing to the $\mathrm{Pb}$ signal seen, thus the green roof substrate may be acting as a store of legacy pollution.

The study highlights the need for consideration of local atmospheric pollution inputs when installing a green roof and the consequent deterioration of runoff quality which may result as the roof ages.

\section{Acknowledgements}

This work was funded by NERC with CASE contributions from Manchester City Council. Advice and assistance was gratefully received from John Moore and Clive Agnew at the University of Manchester. The botanical survey of the roof was carried out by Cameron Crook.

\section{References}

Abbasi, T., Abbasi, S.A., 2011. Sources of pollution in rooftop rainwater harvesting systems and their control. Crit. Rev. Environ. Sci. Technol. 41 (23), 2097-2167.

Barraclough, D., 2007. UK Soil and Herbage Pollutant Survey: UKSHS Report No. 1. Introduction and Summary. Environment Agency, Bristol.

Beck, D.A., Johnson, G.R., Spolek, G.A., 2011. Amending greenroof soil with biochar to affect runoff water quantity and quality. Environ. Pollut. 159 (8-9), 21112118.

Berghage, R., Beattie, D., Jarrett, A., O’Connor, T., 2007. Greenroof runoff water quality. In: Greening Rooftops for Sustainable Communities. Minneapolis, April 29-May 1.

Berndtsson, J.C., 2010. Green roof performance towards management of runoff water quantity and quality: a review. Ecol. Eng. 36 (4), 351-360.

Berndtsson, J.C., Bengtsson, L., Jinno, K., 2009. Runoff water quality from intensive and extensive vegetated roofs. Ecol. Eng. 35 (3), 369-380.

Berndtsson, J.C., Emilsson, T., Bengtsson, L., 2006. The influence of extensive vegetated roofs on runoff water quality. Sci. Total Environ. 355 (1-3), 48-63.

Buss, S.R., Rivett, M.O., Morgan, P., Bemment, C.D., 2005. Attenuation of Nitrate in the Sub-surface Environment. Science Report SC030155/SR2 for the Environment Agency.

Chiaradia, M., Cupelin, F., 2000. Behaviour of airborne lead and temporal variations of its source effects in Geneva (Switzerland): comparison of anthropogenic versus natural processes. Atmos. Environ. 34 (6), 959-971.
CIRIA, 2007. C697, the SUDS Manual. Construction Industry Research and Information Association. www.ciria.org.

Cloy, J.M., Farmer, J.G., Graham, M.C., MacKenzie, A.B., Cook, G.T., 2008. Historical records of atmospheric $\mathrm{Pb}$ deposition in four Scottish ombrotrophic peat bogs: an isotopic comparison with other records from western Europe and Greenland. Global Biogeochem. Cycles 22 (2).

Currie, B.A., Bass, B., 2008. Estimates of air pollution mitigation with green plants and green roofs using the UFORE model. Urban Ecosyst. 11 (4), 409-422.

Czerniawska-Kusza, I., Kusza, G., Duzynski, M., 2004. Effect of deicing salts on urban soils and health status of roadside trees in the Opole region. Environ. Toxicol. 19 (4), 296-301.

DEFRA, 2010. The River Basin Districts Typology, Standards and Groundwater Threshold Values (Water Framework Directive) (England and Wales) Directions 2010. Accessed online at: http://archive.defra.gov.uk/environment/quality/ water/wfd/documents/2010directions.pdf, 15/02/2013.

DEFRA, 2011. Water for Life (White Paper). Defra, London. Accessed online at: http://www.official-documents.gov.uk/, 05/02/2013.

DEFRA, 2012. Tackling Water Pollution from the Urban Environment. Consultation on a Strategy to Address Diffuse Water Pollution from the Built Environment. Defra, London. Available online: www.defra.gov.uk, 05.02.13.

DEFRA, 2013. UK Deposition Data. Available at: http://pollutantdeposition.defra.gov uk/data (accessed 25.02.13). Defra, London (Online). (Accessed).

Del Rio-Salas, R., Ruiz, J., De la O-Villanueva, M., Valencia-Moreno, M., MorenoRodriguez, V., Gomez-Alvarez, A., Grijalva, T., Mendivil, H., Paz-Moreno, F., Meza-Figueroa, D., 2012. Tracing geogenic and anthropogenic sources in urban dusts: Insights from lead isotopes. Atmos. Environ. 60, 202-210.

Dise, N.B., Matzner, E., Gundersen, P., 1998. Synthesis of nitrogen pools and fluxes from European forest ecosystems. Water Air Soil Pollut. 105 (1-2), 143-154.

Dise, N.B., Wright, R.F., 1995. Nitrogen leaching from European forests in relation to nitrogen deposition. For. Ecol. Manage. 71 (1-2), 153-161.

Dunnett, N., Kingsbury, N., 2004. Planting Green Roofs and Living Walls. Timber Press, Portland.

EA, 2011. Environment Agency UK - Chemical Standards Database. Available at: http://evidence.environment-agency.gov.uk/ChemicalStandards/Home.aspx (accessed online 11.02.13).

EA, 2012. Method Statement for Nitrate Vulnerable Zone Review - Eutrophic. Environment Agency report to Defra and Welsh Government - supporting paper for the implementation of the nitrates directive, pp. 2013-2016.

Ellis, J.B., Mitchell, G., 2006. Urban diffuse pollution: key data information approaches for the Water Framework Directive. Water Environ. J. 20 (1), 19-26.

Emilsson, T., Berndtsson, J.C., Mattsson, J.E., Rolf, K., 2007. Effect of using conventional and controlled release fertiliser on nutrient runoff from various vegetated roof systems. Ecol. Eng. 29 (3), 260-271.

Evans, U.R., 1960. The Corrosion and Oxidation of Metals: Scientific Principles and Practical Applications. St. Martin's Press.

FLL, 2008. Forschungsgesellschaft Landschaftsentwicklung Landschaftsbau e. V. (FLL) Guidelines for the Planning, Construction and Maintenance of Green Roofing, English language ed. FLL, Bonn. Available at: www.fll.de.

Fordyce, F.M., Brown, S.E., Ander, E.L., Rawlins, B.G., O’Donnell, K.E., Lister, T.R., Breward, N., Johnson, C.C., 2005. GSUE: urban geochemical mapping in Great Britain. Geochem. Explor. Environ. Anal. 5, 325-336.

Forster, J., 1999. Variability of roof runoff quality. Water Sci. Technol. 39 (5), $137-$ 144.

Fowler, D., Cape, N., Smith, R., Nemitz, E., Sutton, M., Dore, T., Coyle, M., Crossley, A., Storeton-West, R., Muller, J., Phillips, G., Thomas, R., Vieno, M., Yang, S. Famulari, D., Twigg, M., Bealey, B., Benham, D., Hayman, G., Lawrence, H. Vincent, K., Fagerli, H., Simpson, D., 2007. Acid Deposition Processes: RMP 2258 Final Report to Defra. Centre for Ecology and Hydrology.

Fowler, D., McDonald, A.G., Crossley, A., Nemitz, E., Leaver, J.N., Cape, R.I., Smith, D., Anderson, P., Rowland, P., Ainsworth, G., Lawlor, A.J., Guyatt, H., Harmens, H., 2006. UK Heavy Metal Monitoring Network. Project Number EPG 1/3/204 for Defra.

Getter, K.L., Rowe, D.B., Andresen, J.A., 2007. Quantifying the effect of slope on extensive green roof stormwater retention. Ecol. Eng. 31 (4), 225-231.

Göbel, P., Dierkes, C., Coldewey, W.G., 2007. Storm water runoff concentration matrix for urban areas. J. Contam. Hydrol. 91 (1-2), 26-42.

Goodrich, B.A., Koski, R.D., Jacobi, W.R., 2009. Condition of soils and vegetation along roads treated with magnesium chloride for dust suppression. Water Air Soil Pollut. 198 (1-4), 165-188.

Gregoire, B.G., Clausen, J.C., 2011. Effect of a modular extensive green roof on stormwater runoff and water quality. Ecol. Eng. 37 (6), 963-969.

Hayman, G., Hasler, S., Vincent, K., Baker, S., Donovan, B., Smith, M., Davies, M., Sutton, M., Tang, Y.S., Dragosits, U., Love, L., Fowler, D., Sansom, L., Page, H., 2001. Operation and Management of the UK Acid Deposition Monitoring Networks: Data Summary for 2000. AEA Technology report for Defra reference AEAT/ENV/ $\mathrm{R} / 0740$.

Johnson, C.C., Breward, N., Ander, E.L., Ault, L., 2005. G-BASE: baseline geochemical mapping of Great Britain and Northern Ireland. Geochem. Explor. Environ. Anal. 5 (4) $347-357$

Kaczala, F., Marques, M., Vinrot, E., Hogland, W., 2011. Stormwater run-off from an industrial log yard: characterization, contaminant correlation and first-flush phenomenon. Environ. Technol. 33 (14), 1615-1628.

Köhler, M., Schmidt, M., Grimme, F.W., Laar, M., de Assunc-ão Paiva, V.L., Tavares, S. 2002. Green roofs in temperate climates and in the hot-humid tropics-far beyond the aesthetics. Environ. Manage. Health 13 (4). 
Long, B., Clark, S.E., Baker, K.H., Berghage, R., 2006. Green roof media selection for the minimization of pollutant loading in roof run-off. Dallas, TX, October 21-25. In: Proc.. of the Water Environment Federation WEFTEC.

Lundmark, A., Olofsson, B., 2007. Chloride deposition and distribution in soils along a deiced highway - assessment using different methods of measurement. Water Air Soil Pollut. 182 (1-4), 173-185.

Lye, D.J., 2009. Rooftop runoff as a source of contamination: a review. Sci. Total Environ. 407 (21), 5429-5434.

MacKenzie, A.B., Logan, E.M. Cook, G.T., Pulford, I.D., 1998. Distributions, inventories and isotopic composition of lead in $\mathrm{Pb}$-210-dated peat cores from contrasting biogeochemical environments: implications for lead mobility. Sci. Total Environ. 223 (1), 25-35.

MAPAC, 1993. A Breathing Space: Vehicle Related Air Pollution in North West England. Manchester Area Pollution Advisory Council.

Mayes, W.M., Potter, H.A.B., Jarvis, A.P., 2010. Inventory of aquatic contaminant flux arising from historical metal mining in England and Wales. Sci. Total Environ. 408 (17), 3576-3583.

MCC, 2010. Manchester's Population Historically (Online). Available: http://www manchester.gov.uk/downloads/download/4220/corporate_research_and intelligence_population_publications (accessed January 2012).

Mendez, C.B., Klenzendorf, J.B., Afshar, B.R., Simmons, M.T., Barrett, M.E., Kinney, K.A., Kirisits, M.J., 2011. The effect of roofing material on the quality of harvested rainwater. Water Res. 45 (5), 2049-2059.

Mentens, J., Raes, D., Hermy, M., 2006. Green roofs as a tool for solving the rainwater runoff problem in the urbanized 21st century? Landsc. Urban Plan. 77 (3), 217 226.

Mitchell, G.N., 1990. Natural discoloration of freshwater: chemical and environmental genesis. Prog. Phys. Geogr. 14, 317-334.

Monterusso, M.A., Rowe, D.B., Rugh, C.L., Russell, D.K., 2004. Runoff water quantity and quality from green roof systems. Acta Hortic. 639, 369-376.

Moran, A., Hunt, B., Jennings, G., 2003. A North Carolina Field Study to Evaluate Greenroof Runoff Quality, Runoff Quantity, and Plant Growth. ASAE Paper 032303. Am. Soc. of Agric. Eng., St. Joseph, MI.

NAEI, 2013. National Atmospheric Emissions Inventory (NAEI) UK Emissions Dat Selector (Online). Available: http://naei.defra.gov.uk/data/ (accessed 28.03.13).

Pizzol, M., Christensen, P., Schmidt, J., Thomsen, M., 2011. Eco-toxicological impact of "metals" on the aquatic and terrestrial ecosystem: a comparison between eight different methodologies for Life Cycle Impact Assessment (LCIA) J. Cleaner Prod. 19 (6-7), 687-698.

Robertson, D.J., Taylor, K.G., 2007. Temporal variability of metal contamination in urban road-deposited sediment in Manchester, UK: implications for urban pollution monitoring. Water Air Soil Pollut. 186 (1-4), 209-220.

Robertson, D.J., Taylor, K.G., Hoon, S.R., 2003. Geochemical and mineral magnetic characterisation of urban sediment particulates, Manchester, UK. Appl. Geochem. 18 (2), 269-282.
Rocher, V., Azimi, S., Gasperi, J., Beuvin, L., Muller, M., Moilleron, R., Chebbo, G., 2004. Hydrocarbons and metals in atmospheric deposition and roof runoff in central Paris. Water Air Soil Pollut. 159 (1-4), 67-86.

Rothwell, J.J., Evans, M.G., Daniels, S.M., Allott, T.E.H., 2008. Peat soils as a source of lead contamination to upland fluvial systems. Environ. Pollut. 153 (3), 582-589.

Rowe, D.B., 2011. Green roofs as a means of pollution abatement. Environ. Pollut. 159 (8-9), 2100-2110

Simmons, G., Hope, V., Lewis, G., Whitmore, J., Gao, W., 2001. Contamination of potable roof-collected rainwater in Auckland, New Zealand. Water Res. 35 (6), 1518-1524.

Speak, A.F., Rothwell, J.J., Lindley, S.J., Smith, C.L., 2012. Urban particulate pollution reduction by four species of green roof vegetation in a UK city. Atmos. Environ. 61 (0), 283-293.

Speak, A.F., Rothwell, J.J., Lindley, S.J., Smith, C.L., 2013. Rainwater runoff retention on an aged intensive green roof. Sci. Total Environ. 461-462, 28-38.

Stewart, I.D., Oke, T.R., 2012. Local climate zones for urban temperature studies. Bull. Am. Meteorol. Soc. 93, 1879-1900.

Stovin, V., Vesuviano, G., Kasmin, H., 2012. The hydrological performance of a green roof test bed under UK climatic conditions. J. Hydrol. 414-415 (0), 148-161.

Sumner, M.E., 2000. Handbook of Soil Science. CRC Press, Florida.

Taylor, K.G., Robertson, D.J., 2009. Electron microbeam analysis of urban roaddeposited sediment, Manchester, UK: improved source discrimination and metal speciation assessment. Appl. Geochem. 24 (7), 1261-1269.

Teemusk, A., Mander, U., 2007. Rainwater runoff quantity and quality performance from a greenroof: the effects of short-term events. Ecol. Eng. 30 (3), 271-277.

Teemusk, A., Mander, U., 2011. The influence of green roofs on runoff water quality: a case study from Estonia. Water Resour. Manage. 25 (14), 3699-3713.

Tijhuis, L., Brattli, B., Sæther, O.M., 2002. A geochemical survey of topsoil in the city of Oslo, Norway. Environ. Geochem. Health 24 (1), 67-94.

UoM, 2012. University of Manchester - the Whitworth Meteorological Observatory (Online). Available: http://www.cas.manchester.ac.uk/restools/whitworth/data/ (accessed March 2012).

Vijayaraghavan, K., Joshi, U.M., Balasubramanian, R., 2012. A field study to evaluate runoff quality from green roofs. Water Res. 46 (4), 1337-1345.

Wallage, Z.E., Holden, J., McDonald, A.T., 2006. Drain blocking: an effective treatment for reducing dissolved organic carbon loss and water discolouration in a drained peatland. Sci. Total Environ. 367 (2-3), 811-821.

White, P.J., Broadley, M.R., 2001. Chloride in soils and its uptake and movement within the plant: a review. Ann. Bot. 88 (6), 967-988.

Young, T.M., Heeraman, D.A., Sirin, G., Ashbaugh, L.L., 2002. Resuspension of soil as a source of airborne lead near industrial facilities and highways. Environ. Sci. Technol. 36 (11), 2484-2490.

Zuo, X., Fu, D., Li, H., 2012. Speciation distribution and mass balance of copper and zinc in urban rain, sediments, and road runoff. Environ. Sci. Pollut. Res. 19 (9), 4042-4048. 